\title{
North Atlantic forcing of tropical Indian Ocean climate
}

\author{
Mahyar Mohtadi ${ }^{1 *}$, Matthias Prange ${ }^{1}$, Delia W. Oppo ${ }^{2}$, Ricardo De Pol- \\ Holz $^{3}$, Ute Merkel ${ }^{1}$, Xiao Zhang $^{1}$, Stephan Steinke ${ }^{1}$ \& Andreas Lückge ${ }^{4}$ \\ ${ }^{1}$ MARUM-Center for Marine Environmental Sciences, University of Bremen, 28359 Bremen, \\ Germany \\ ${ }^{2}$ Geology and Geophysics, Woods Hole Oceanographic Institution, Woods Hole, \\ Massachusetts 02543, USA \\ ${ }^{3}$ Department of Oceanography, University of Concepción, Concepción, Chile. ${ }^{4}$ Federal \\ Institute for Geosciences and Natural Resources, 30655 Hannover, Germany. \\ * Corresponding author (mmohtadi@marum.de)
}

The response of the tropical climate in the Indian Ocean realm to abrupt climate change events in the North Atlantic Ocean is contentious. Repositioning of the intertropical convergence zone is thought to have been responsible for changes in tropical hydroclimate during North Atlantic cold spells $^{1-5}$, but the dearth of high-resolution records outside the monsoon realm in the Indian Ocean precludes a full understanding of this remote relationship and its underlying mechanisms. Here we show that slowdowns of the Atlantic meridional overturning circulation during Heinrich stadials and the Younger Dryas stadial affected the tropical Indian Ocean hydroclimate through changes to the Hadley circulation including a southward shift in the rising branch (the intertropical convergence zone) and an overall weakening over the southern Indian Ocean. Our results are based on new, high-resolution sea surface temperature and seawater oxygen isotope records of well dated sedimentary archives from the tropical eastern Indian Ocean for the past 45,000 years, combined with climate model simulations of Atlantic circulation slowdown under Marine Isotope Stages 2 and 3 boundary conditions. Similar conditions in the east and west of the basin rule out a zonal dipole structure as the dominant forcing of the tropical Indian Ocean hydroclimate of millennial-scale events. Results from our simulations and proxy data suggest dry conditions in the northern Indian Ocean realm and wet and warm conditions in the southern realm during North Atlantic cold spells.

In the North Atlantic, the most recent glacial and deglacial periods are characterized by a series of abrupt and severe cold snaps of millennial duration associated with either iceberg instabilities and surges (Heinrich events) or freshwater input from the Arctic Ocean ${ }^{6}$ (the Younger Dryas). These abrupt events are of particular interest because they were rapidly communicated through the ocean by a slowdown, or potentially a shutdown, of the Atlantic meridional overturning circulation ${ }^{7}$ (AMOC) and through the atmospheric circulation ${ }^{8}$ causing climate anomalies worldwide. Climate archives document a significant tropical hydrologic response to these events. Dry Younger Dryas and Heinrich stadials have been reported from various marine and terrestrial archives across the tropical Indian Ocean ${ }^{4,9-14}$.However, a few records suggest wet Younger Dryas or Heinrich stadials over northeast Australia ${ }^{15}$, southern Indonesia ${ }^{5,16}$ and southeast Africa ${ }^{12,17}$.

Although there seems to be strong evidence that the intertropical convergence zone (ITCZ) moved southwards in the tropical Atlantic ${ }^{2}$, a wide range of mechanisms have been offered to explain the connection between the cooling of the North Atlantic and 
tropical Indian Ocean hydroclimates: a weakening of the rainfall system in response to regional sea surface cooling ${ }^{13,14}$; and changes in the monsoon intensity ${ }^{4,10,16}$ associated with a southward shift in the mean ${ }^{1}$ or winter ${ }^{4,5,15}$ position of the ITCZ or in the position of oceanic fronts ${ }^{18}$. However, there are no high-resolution records from the region of the tropical Indian Ocean unaffected by monsoon seasonality. Records from this region are needed to evaluate whether the eastern and western Indian Ocean experienced similar or contrasting rainfall anomalies during abrupt climate events. Furthermore, the Younger Dryas signal in many of the available records is ambiguous at best, and almost none of them include data associated with North Atlantic millennial events older than Heinrich stadial 1.

The effect of AMOC slowing on tropical climate can be studied with freshwater hosing experiments using coupled atmosphere-ocean general circulation models. Such numerical experiments consistently show a southward displacement of the ITCZ over the Atlantic Ocean in response to North Atlantic cooling induced by a perturbation of the $A M O C^{1,19,20}$. However, these experiments provide ambiguous results for the tropical Indo-Pacific region, with the response and sensitivity of the region to North Atlantic freshwater perturbations being strongly model dependent $\mathrm{t}^{20}$. Thus, palaeoclimate data are invaluable for identifying mechanisms of hydrologic change outside the Atlantic realm.

Here we present three high-resolution marine sedimentary records from the western coast of Sumatra spanning the past $45 \mathrm{kyr}$. The age models for these cores are well constrained and are based on a total of 162 radiocarbon dates (Methods and Supplementary Table 1). We measured shell $\mathrm{Mg} / \mathrm{Ca}$ ratios (806 samples) and stable oxygen isotopes $\left(\delta^{18} \mathrm{O} ; 1,191\right.$ samples) of the surface-dwelling planktonic foraminifera Globigerinoides ruber sensu stricto to reconstruct variations in seawater $\delta^{18} \mathrm{O}\left(\delta^{18} \mathrm{O}_{\mathrm{sw}}\right.$; Methods). These records include the first high-resolution paired $\mathrm{Mg} / \mathrm{Ca}-\delta 18 \mathrm{O}_{\mathrm{sw}}$ record (average sampling time, $60 \mathrm{yr}$ ) from the equatorial eastern Indian Ocean, which provides a measure of hydrological changes during the past

$45 \mathrm{kyr}$ (Fig. 1). Modern observations and instrumental records from the non-upwelling fore-arc basins off northern and central Sumatra, where our sites are located, suggest minor seasonal changes in precipitation, sea surface temperature (SST) and salinity compared with the upwelling region off south Java, and confirm that the study area lies outside the main Australasian monsoonal rainfall domains (Methods). Whereas records from other areas of the Indo-Pacific warm pool may be decoupled from local precipitation owing to oceanic advection ${ }^{21}$, salinity at our core sites is primarily driven by local rainfall and runoff (Methods). We therefore infer that the observed changes in our proxy records reflect local precipitation and can be used to unravel the response of the tropical eastern Indian Ocean during the Younger Dryas and Heinrich events.

Reconstructed SST, $\delta^{18} \mathrm{O}$ and $\delta^{18} \mathrm{O}_{\text {sw }}$ from all sites show a remarkably consistent pattern during times when they overlap (Fig. 1), suggesting a coherent response from central to northern Sumatra. The SST records indicate that the deglacial warming of about $3{ }^{\circ} \mathrm{C}$ started $18,300 \pm 330 \mathrm{yr}$ ago $(1 \sigma$; see Methods), synchronously (within dating uncertainties) with southern high-latitude climate change and an increase in atmospheric $\mathrm{CO}_{2}$ concentration occurring during this period ${ }^{22}$ (Fig. 2).

Although the sea-level-corrected $\delta^{18} \mathrm{O}_{\text {sw }}$ records show no glacial-interglacial change, the values increase during the Northern Hemisphere climate cold spells, as recorded in Greenland ice cores. Our records suggest decreased precipitation in the tropical eastern Indian Ocean that is most prominent during Heinrich stadials 1 and 4 and the Younger Dryas (Fig. 2). The difference between the age of Heinrich stadial 4 as defined in our marine records from off Sumatra and that derived from Greenland ice 
cores or Chinese speleothems (Fig. 2) is within the average $2 \sigma$ error, which is larger than $2 \mathrm{kyr}$ in sediment older than $35 \mathrm{kyr}$ (Methods). Thus, on the basis of the similar timing of younger millennial events in our $\delta^{18} \mathrm{O}_{\mathrm{sw}}$ record and North Atlantic cold events, we argue that the high $\delta^{18} \mathrm{O}_{\mathrm{sw}}$ interval near the documented age of Heinrich event 4 defined by layers containing peaks of ice-rafted detritus in North Atlantic marine records ${ }^{23}$ is also synchronous with that event.

To elucidate the dynamics of changes in the tropical Indian Ocean hydroclimate forced by the North Atlantic, we performed and analysed freshwater hosing experiments under Marine Isotope Stages (MISs) 2 and 3 boundary conditions using the comprehensive coupled climate model CCSM3. More precisely, baseline simulations of the Last Glacial Maximum (LGM; $21 \mathrm{kyr}$ ago (MIS2)) and the time slice from $38 \mathrm{kyr}$ ago (MIS3) were perturbed by $0.2 \mathrm{~Sv}\left(1 \mathrm{~Sv}=10^{6} \mathrm{~m}^{3} \mathrm{~s}^{-1}\right)$ freshwater injections into the northern North Atlantic for $500 \mathrm{yr}$, mimicking Heinrich events 1 and 4 (Methods), two of the most pronounced events in our records. North Atlantic water hosing results in a drastic slowdown of the AMOC by $\sim 10 \mathrm{~Sv}$ in both glacial experiments (Methods) and, owing to the reduced northward Atlantic heat transport, a cooling of the surface of the North Atlantic (Fig. 3a). This cooling quickly propagates zonally throughout the Northern Hemisphere through atmospheric advection by the westerly winds and mixing ${ }^{19}$. The tropical mean circulation responds to the Northern Hemisphere cooling (and Southern Hemisphere warming) by generating anomalous energy transport from the southern hemisphere to the Northern Hemisphere. This energy transport is accomplished by a reorganization of the mean Hadley circulation involving an anomalous northward cross-equatorial flow in the upper branch accompanied by an anomalous southward flow in the lower branch $^{24}$. Over the southern Indian Ocean, this results in a weakening of the annual mean Hadley circulation involving a southward shift of its rising branch, reflected by a north-south dipole structure in the mid-tropospheric vertical velocity anomaly (Fig. $3 b)$. The reorganization of the Hadley circulation is associated with a westerly, lowlevel wind anomaly over the equatorial and south equatorial Indian Ocean (Fig. 3c; northwesterly at the surface (not shown)). This weakening of the southeast trade winds that cross the Equator reduces upwelling in the Arabian Sea (where there are weaker southwesterly winds), as also suggested by proxy records from this region ${ }^{25}$. Moreover, strengthening of the eastward winds over the Equator, a unique feature in the Indian Ocean responsible for warm equatorial waters, also contributes to the warming in the eastern tropical Indian Ocean.

The vertical velocity anomalies are associated with precipitation anomalies inducing drier conditions over the equatorial and north Indian Ocean and more humid conditions south of there (Fig. 3c). In particular, the model simulates a negative rainfall anomaly over Sumatra, whereas rainfall over southern Indonesia increases. The regional climatic response is qualitatively the same in both glacial hosing experiments (that is, under LGM and MIS3 boundary conditions), indicating that the same mechanisms may have been at work during all Heinrich stadials of the last glacial period (Fig. 3d and Methods). Despite the caveat of using a single model, the model results are consistent with our proxy data and also with Heinrich stadial 1 signals from other sites in the tropical Indian Ocean realm. Records suggesting humid conditions in Southern Indonesia and northern Australia during the Younger Dryas and Heinrich stadial $1^{5,15,16}$ lie within the easternmost part of the anomalous Indian Ocean Hadley cell, which is confined by the ascending branch of the Pacific Walker cell (Fig. 3). Likewise, lake records from East Africa that suggest humid conditions during Heinrich stadial $1^{12,17}$ lie beneath the ascending branch of the anomalous Hadley cell (Fig. 3). The remaining records of hydrological changes from 
the equatorial and northern Indian Ocean ${ }^{26,27}$ (including our records) suggest drier conditions during Heinrich stadial 1, in agreement with our model simulation. As part of the Hadley cell reorganization during Heinrich stadials, the Indian summer monsoon weakens. This weakening has been recently attributed to anomalous SST forcing in the tropical Atlantic that affects the Indian monsoon via a tropical atmospheric pathway ${ }^{3}$. Our model results suggest a rapid response of the Indian monsoon to North Atlantic abrupt events through both a stationary Rossby wave-train teleconnection that originates in the northern North Atlantic and a tropical atmospheric pathway (Methods).

Our results suggest that the North Atlantic climate cold spells affect the hydrology of the tropical Indian Ocean through a reorganization of the Hadley circulation including a southward displacement of the ITCZ. This finding suggests that northern Indian Ocean cooling alone cannot explain tropical Indian Ocean hydrology during the Younger Dryas and Heinrich stadials. Indeed, our SST reconstructions show a slight warming during several Heinrich stadials, suggesting that at least in central-northern Sumatra, reduced rainfall was not a response to local SST cooling. Comparison of our data from the eastern tropical Indian Ocean with the Lake Tanganyika humidity record from East Africa ${ }^{14}$ reveals a strong similarity $(r=0.43$ with the range [0.11, 0.67], 95\% confidence interval; Methods) with dry Younger Dryas and Heinrich stadials on both sides of the tropical Indian Ocean (Fig. 2), and suggests that zonally asymmetric changes within the Indian Ocean ${ }^{14}$ were not the main control on Indian Ocean hydrology during these periods. Our results suggest that decreases in the monsoon intensity ${ }^{28}$ stem from a reorganization of the Hadley cell over the Indian Ocean realm (Fig. 3), with heterogeneous mean annual and seasonal SST anomalies over the tropical Indian Ocean (Methods).

Integrated palaeoclimate data and model results from this study reveal that drastic changes in the tropical Indian Ocean climate appear as a robust response to the AMOC slowdown during Heinrich stadials and the Younger Dryas. This response involves similar mechanisms regardless of glacial background climate states. These climatic changes involve a reorganization of the Hadley circulation, with a southward shift of the ITCZ across the entire equatorial Indian Ocean. The resulting precipitation anomaly mirrors the meridional dipole-shaped rainfall anomaly in the tropical Atlantic region $^{2}$. By contrast, our data suggesting little glacial-interglacial hydrologic change in the eastern Indian Ocean add to a growing body of evidence that the response of regional hydroclimate on millennial timescales was substantially greater than that on glacial-interglacial timescales ${ }^{21,26}$.

\section{METHODS SUMMARY}

Piston cores SO189-119KL $\left(3^{\circ} 31^{\prime} \mathrm{N}, 96^{\circ} 19^{\prime} \mathrm{E}\right.$; 780-cm core length, 808-m water depth), SO189-144KL (1० $9^{\prime} \mathrm{N}, 98^{\circ} 4^{\prime} \mathrm{E}$; 822-cm core length, 481-m water depth) and SO189-39KL $\left(0^{\circ} 47^{\prime} \mathrm{S}\right.$, $99^{\circ} 54^{\prime} \mathrm{E} ; 1,350-\mathrm{cm}$ core length, 517-m water depth) were collected from the fore-arc basins off western Sumatra: the Simeulue basin $(119 \mathrm{KL})$, the Nias basin (144KL) and the northern Mentawai basin (39KL). Age models were based on linear interpolation between a total of 162 radiocarbon dates (Supplementary Table 1 and Extended Data Fig. 4). For $\delta^{18} \mathrm{O}$ analysis, the isotopic composition of the carbonate sample was measured using a Finnigan MAT 251 mass spectrometer on the $\mathrm{CO}_{2}$ gas evolved by treatment with phosphoric acid at a constant temperature of $75^{\circ} \mathrm{C}$. The $\mathrm{Mg} / \mathrm{Ca}$ cleaning protocol consisted of five water and two methanol washes, two oxidation steps with $1 \% \mathrm{NaOH}$-buffered $\mathrm{H}_{2} \mathrm{O}_{2}$, and a weak acid leach with $0.001 \mathrm{M} \mathrm{QD} \mathrm{HNO}_{3}$. Samples were then dissolved into $0.075 \mathrm{M}$ $\mathrm{QD} \mathrm{HNO}_{3}$ and centrifuged for $10 \mathrm{~min}$ at 6,000 r.p.m., transferred into test tubes and 
diluted. Mg/Ca ratios were measured using a Perkin Elmer Optima $3300 \mathrm{R}$ inductively coupled plasma optical emission spectrophotometer for samples from core 199KL, and an Agilent Technologies 700 Series inductively coupled plasma optical emission spectrophotometer for samples from core 39KL. For details, see Methods and Extended Data. For the numerical experiments, the comprehensive global climate model CCSM3 was used. The baseline simulations for LGM and MIS3 comprise the orbital parameters, greenhouse gas concentrations, sea level and continental ice sheets at, respectively, 21 and $38 \mathrm{kyr}$ ago. For the Heinrich stadial 1 and 4 experiments, the LGM and, respectively, MIS3 climate states were perturbed by a constant freshwater input of $0.2 \mathrm{~Sv}$ to the northern North Atlantic. The hosing experiments were integrated for $500 \mathrm{yr}$. For each experiment, the mean of the past 100 simulation years was used for analysis. For details, see Methods and Extended Data.

\section{References:}

1. Lewis, S. C. et al. High-resolution stalagmite reconstructions of Australian-Indonesian monsoon rainfall variability during Heinrich stadial 3 and Greenland interstadial 4. Earth Planet. Sci. Lett. 303, 133-142 (2011).

2. Arbuszewski, J. A., deMenocal, P. B., Cleroux, C., Bradtmiller, L. \& Mix, A. Meridional shifts of the Atlantic intertropical convergence zone since the Last Glacial Maximum. Nature Geosci. 6, 959-962 (2013).

3. Marzin, C., Kallel, N., Kageyama, M., Duplessy, J.-C. \& Braconnot, P. Glacial fluctuations of the Indian monsoon and their relationship with North Atlantic climate: new data and modelling experiments. Clim. Past 9, 2135-2151 (2013).

4. Mohtadi, M. et al. Glacial to Holocene swings of the Australian-Indonesian monsoon. Nature Geosci. 4, 540-544 (2011).

5. Muller, J., McManus, J. F., Oppo, D. W. \& Francois, R. Strengthening of the Northeast Monsoon over the Flores Sea, Indonesia, at the time of Heinrich event 1. Geology 40, 635-638 (2012).

6. Condron, A. \& Winsor, P. Meltwater routing and the Younger Dryas. Proc. Nat. Acad. Sci. USA 109, 19928-19933 (2012).

7. McManus, J. F., Francois, R., Gherardi, J. M., Keigwin, L. D. \& Brown-Leger, S. Collapse and rapid resumption of Atlantic meridional circulation linked to deglacial climate changes. Nature 428, 834-837 (2004).

8. Moreno, P. I., Jacobson, G. L., Lowell, T. V. J. \& Denton, G. H. Interhemispheric climate links revealed by a late-glacial cooling episode in southern Chile. Nature 409, 804-808 (2001).

9. Deplazes, G. et al. Links between tropical rainfall and North Atlantic climate during the last glacial period. Nature Geosci. 6, 213-217 (2013).

10. Mohtadi, M., Steinke, S., Lückge, A., Groeneveld, J. \& Hathorne, E. C. Glacial to Holocene surface hydrography of the tropical eastern Indian Ocean. Earth Planet. Sci. Lett. 292, 89-97 (2010).

11. Partin, J. W., Cobb, K. M., Adkins, J. F., Clark, B. \& Fernandez, D. P. Millennial-scale trends in west Pacific warm pool hydrology since the Last Glacial Maximum. Nature 449, 452-455 (2007).

12. Thomas, D. S. G., Burrough, S. L. \& Parker, A. G. Extreme events as drivers of early human behaviour in Africa? The case for variability, not catastrophic drought. J. Quaternary Sci. 27, 7-12 (2012).

13. Stager, J.C., Ryves, D. B.,Chase,B.M. \& Pausata, F. S. R. Catastrophic drought in the Afro-AsianmonsoonregionduringHeinrichevent 1. Science 331,1299-1302(2011).

14. Tierney, J. E. et al. Northern hemisphere controls on tropical southeast African Climate during the past 60,000 years. Science 322, 252-255 (2008).

15. Muller, J. et al. Possible evidence for wet Heinrich phases in tropical NE Australia: the Lynch's crater deposit. Quat. Sci. Rev. 27, 468-475 (2008). 
16. Griffiths, M. L. et al. Increasing Australian-Indonesian monsoon rainfall linked to early Holocene sea-level rise. Nature Geosci. 2, 636-639 (2009).

17. Schefuß, E., Kuhlmann, H., Mollenhauer, G., Prange, M. \& Pätzold, J. Forcing of wet phases in southeast Africa over the past 17,000 years. Nature 480, 509-512 (2011).

18. De Deckker, P., Moros, M., Perner, K. \& Jansen, E. Influence of the tropics and southern westerlies on glacial interhemispheric asymmetry. Nature Geosci. 5, 266269 (2012).

19. Clement, A. C. \& Peterson, L. C. Mechanisms of abrupt climate change of the last glacial period. Rev. Geophys. 46, RG4002 (2008).

20. Kageyama, M. et al. Climatic impacts of fresh water hosing under Last Glacial Maximum conditions: a multi-model study. Clim. Past 9, 935-953 (2013).

21. Gibbons, F. T. et al. Deglacial $\delta^{18} \mathrm{O}$ and hydrologic variability in the tropical Pacific and Indian Oceans. Earth Planet. Sci. Lett. 387, 240-251 (2014).

22. Parrenin, $F$. et al. Synchronous change of atmospheric $\mathrm{CO}_{2}$ and Antarctic temperature during the Last Deglacial Warming. Science 339, 1060-1063 (2013).

23. Hemming, S. R. Heinrich events: massive late Pleistocene detritus layers of the North Atlantic and their global climate imprint. Rev. Geophys. 42, RG1005 (2004).

24. Frierson, D. M. W. et al. Contribution of ocean overturning circulation to tropical rainfall peak in the Northern Hemisphere. Nature Geosci. 6, 940-944 (2013).

25. Pourmand, A., Marcantonio, F. \& Schulz, H. Variations in productivity and eolian fluxes in the northeastern Arabian Sea during the past $110 \mathrm{ka}$. Earth Planet. Sci. Lett. 221, 39-54 (2004).

26. Carolin, S. A. et al. Varied response of Western Pacific hydrology to climate forcings over the Last Glacial Period. Science 340, 1564-1566 (2013).

27. Verschuren, D. et al. Half-precessional dynamics of monsoon rainfall near the East African Equator. Nature 462, 637-641 (2009).

28. Tierney, J. E. \& deMenocal, P. B. Abrupt shifts in Horn of Africa hydroclimate since the Last Glacial Maximum. Science 342, 843-846 (2013).

29. Svensson, A. et al. A 60,000 year Greenland stratigraphic ice core chronology. Clim. Past 4, 47-57 (2008).

30. Wang, Y. et al. Millennial- and orbital-scale changes in the East Asian monsoon over the past 224,000 years. Nature 451, 1090-1093 (2008).

\section{Acknowledgements}

We are grateful to K. Olafsdottir, M. Segl and B. Meyer-Schack for technical support. This study was funded by the German Bundesministerium für Bildung und Forschung (grant 03G0189A) and the Deutsche Forschungsgemeinschaft (DFG grants HE3412/15-1 and STE1044/4-1, and the DFG Research Centre/Cluster of Excellence 'The Ocean in the Earth System'). Climate model simulations were performed on the SGI Altix super computer of the Norddeutscher Verbund für Hoch- und Höchstleistungsrechnen. D.W.O. is funded by the US NSF, R.D.P.-H. is supported by Chilean FONDAP 15110009/ICM Nucleus NC120066.

\section{Author Contributions}

M.M., D.W.O. and A.L. designed the study. M.P., U.M. and X.Z. designed, performed and analysed the climate model experiments. M.M. and S.S. generated and analysed the proxy data. R.D.P.-H., M.M. and D.W.O. were responsible for the radiocarbon analyses. M.M. and M.P. wrote the manuscript; all authors discussed the manuscript.

\section{Figure 1}

Hydroclimate records from the eastern tropical Indian Ocean. Time series of $\delta^{18} \mathrm{O}=\left({ }^{18} \mathrm{O} /{ }^{16} \mathrm{O}\right)$ sample $/\left({ }^{18} \mathrm{O} /{ }^{16} \mathrm{O}\right.$ ) standard -1 (where the standard is PeeDee Belemnite (PDB)) (a), SST (b) and $\delta^{18} \mathrm{O}_{\text {sw }}$ (seawater $\delta^{18} \mathrm{O}$ with standard mean ocean water as the standard) (c). The chronology of each core is established independently 
by ${ }^{14} \mathrm{C}$ accelerator mass spectrometry dating (triangles; see Methods). There is a large similarity between all records during the time they overlap, with no glacialinterglacial difference in the sea-level-corrected $\delta^{18} \mathrm{O}_{\mathrm{sw}}$.

\section{Figure 2}

Comparison of East Indian Ocean $\delta^{18} \mathrm{O}_{\text {sw }}$ and SST data with other records of palaeoclimate. $\mathbf{a}, \delta^{18} \mathrm{O}$ data of Greenland ice core NGRIP ${ }^{29}$; $\mathbf{b}$, stack $\delta^{18} \mathrm{O}$ record of Chinese speleothems ${ }^{30}$; c, deuterium isotopes $(\delta D)$ of leaf wax from Lake Tanganyika ${ }^{14}$; d, sea-level-corrected $\delta^{18} \mathrm{O}_{\text {sw }}$ of core $39 \mathrm{KL}$ off western Sumatra (this study; black line represents a 7-point running average); e, SST reconstruction at site $39 \mathrm{KL}$ off western Sumatra (this study). Envelopes in $\mathbf{d}$ and $\mathbf{e}$ indicate $1 \sigma$ errors (Methods). $\mathbf{f}, \delta D$ data from the EPICA Dome $\mathrm{C}$ ice core ${ }^{22} . \mathbf{g}$, Deglacial $\mathrm{CO}_{2}$ record from the EPICA Dome C ice core ${ }^{22}$. Grey bars indicate the $8.2 \mathrm{kyr}$ event, the Younger Dryas (YD), and Heinrich stadials (HSs) 1 to 4 as recorded in North Atlantic deep-sea cores $^{23}$. Triangles indicate the accelerator mass spectrometry ${ }^{14} \mathrm{C}$ age control points for core $39 \mathrm{KL}$ (this study).

\section{Figure 3}

Results from the CCSM3 simulations of Heinrich stadials 1 and 4. Plots show the difference between the Heinrich (hosing) experiments and the baseline simulations (MIS3 for $\mathrm{H} 4$ and $\mathrm{LGM}$ for $\mathrm{H} 1$; see Methods) as annual means. a, Surface temperature anomaly during $\mathrm{H} 4$, showing cooling over the Northern Hemisphere and warming in the Southern Hemisphere. b, Vertical velocity anomaly in the mid-level (500-hPa) atmosphere, with negative and positive values respectively indicating anomalously rising and sinking air during $\mathrm{H} 4$. The ascending branch of the annual mean Hadley circulation over the Indian Ocean is displaced southwards. c, $850-\mathrm{hPa}$ wind (arrows) and precipitation (shading) anomalies during H4. Westerly low-level wind anomalies are associated with wetter southern Indian Ocean and drier equatorial and northern Indian Ocean. d, Same as $\mathbf{c}$ but for the simulation of $\mathrm{H} 1$. Note the similarity between $\mathbf{c}$ and $\mathbf{d}$, and the competing influence of the Pacific Walker cell on the eastern part of the maritime continent. Red stars (this study) and dots $^{4,10,14,27}$ show sites indicating dry conditions during Heinrich stadial 1; blue dots show sites indicating wet Heinrich stadial 1 or Younger Dryas $5,12,16,17$.

\section{METHODS}

\section{Modern climate of the study area}

At present the study area is characterized by only moderate monthly or seasonal changes in SST, air temperature, sea surface salinity (SSS) and precipitation (Extended Data Fig. 1). Mean annual SST averaged between 1854 and 2008 is about $29^{\circ} \mathrm{C}$ with a small seasonal range of only $1.2^{\circ} \mathrm{C}$ for the Simeulue basin, and $1.1{ }^{\circ} \mathrm{C}$ for the northern Mentawai and Nias basins (Extended Data Fig. 1, http://nomads.ncdc.noaa.gov/las/getUl.do). Likewise, 24-h air temperatures show little variability and are on average $26.7^{\circ} \mathrm{C}$ with a small seasonal range of $2{ }^{\circ} \mathrm{C}$ near the core 119KL (station Sabang, averaged between 1976 and 1989; Extended Data Fig. 1) and one of $26.3{ }^{\circ} \mathrm{C}$ with a seasonal range of $0.9{ }^{\circ} \mathrm{C}$ near the core $39 \mathrm{KL}$ (station Padang, averaged between 1850 and 1989; http://climexp.knmi.nl; Extended Data Fig. 1). Generally, SST and air temperatures are highest during boreal spring because that is when near-surface winds are weakest, and are lowest during boreal fall owing to increased cloudiness and rainfall. Mean annual SSS is around 33.5 p.s.u. and varies seasonally within only \pm 0.2 p.s.u. (ref. 31). Instrumental records of precipitation between 1879 and 1989 show higher average monthly rainfall over 
central-western Sumatra ( $360 \mathrm{~mm}$ per month) compared with northwestern Sumatra ( 135mm per month) (http://climexp.knmi.nl; Extended Data Fig. 1). Although there are two precipitation maxima in the study area during spring and fall related to the seasonal migration of the $\mathrm{ITCZ}^{32}$, the contribution of each season to the total amount of rainfall does not vary considerably ( $25 \% \pm 5 \%$; Extended Data Fig. 1).

These findings corroborate previous studies that exclude northern and western Sumatra from the Australasian monsoonal rainfall domains (see, for example, refs $32,33)$. Observation and model studies suggest that there is no significant correlation between SST and rainfall variability in this region, between rainfall and $\mathrm{ENSO}^{32}$, or between SST and $\mathrm{ENSO}^{34}$. In summary, the study area seems ideal to study the evolution of the hydrological changes in the tropical eastern Indian Ocean without significant biases introduced by variations in seasonal or interannual climate phenomena such as monsoon or ENSO.

The oceanic surface currents in the tropical eastern Indian Ocean flow according to the seasonally reversing monsoon winds. During boreal summer, a small branch of the northward flowing southwest monsoon current flows eastwards and joins the north equatorial counter current. This surface current is deflected southwards off the Sumatran coast and meets the south Java current off southwestern Sumatra (Extended Data Fig. 2). During summer, about $6 \mathrm{~Sv}$ of surface water flows southwards with the cross-equatorial meridional Ekman transport (MET), involving the export of low-salinity waters from the Bay of Bengal ${ }^{35-37}$. During boreal winter, the direction of currents in the tropical eastern Indian Ocean is reversed (Extended Data Fig. 2). Westwards flowing surface waters join the northeast monsoon current south of Sri Lanka and are affected by the northwards-directed MET ${ }^{35,37}$. Despite the seasonality in the currents, it seems that SST and SSS off northwestern Sumatra are not considerably affected by seasonally reversing surface current direction in the eastern Indian Ocean ${ }^{37}$ or the strong salinity changes in the Bay of Bengal (see, for example, ref. 38; see also the next section).

\section{Present and past control of $\delta^{18} \mathrm{O}_{\mathrm{sw}}$}

The cores presented in this study have been collected close to the Sumatran coast that is separated from the open ocean by the Simeulue, Nias and Mentawai islands. During the last glacial period and Heinrich stadials, when sea level was up to $130 \mathrm{~m}$ lower than today, these fore-arc basins were more separated from the open ocean owing to their shallow sills of mostly $\sim 130 \mathrm{~m}$ (Extended Data Fig. 3). For the present, observation and model results suggest that "to the west of Sumatra, in particular, large rainfall and runoff persist year-round with enhanced surface stratification" 39 and that salinity off western Sumatra is strongly controlled by precipitation ${ }^{40-42}$. Western

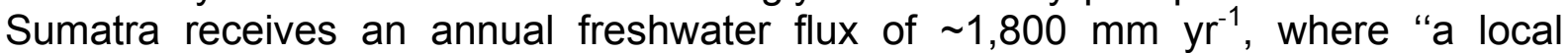
maximum in P-E is present during all months, indicating that rainfall contributes to the existence of salinity stratified surface layer in this region" ${ }^{\prime 2}$. This overriding control of $\delta^{18} \mathrm{O}_{\text {sw }}$ by local rainfall amount is also mirrored in our CTD data from two expeditions in 2005 and 2006 in this region: surface salinity at the core sites ranges between 32.5 p.s.u. (SO189-120MS at site $119 \mathrm{KL}$ and SO189-44MS at site $144 \mathrm{KL}$ ) and 33 p.s.u. (SO189-40MS at site $39 \mathrm{KL}$ ), whereas surface salinity west of the Mentawai Islands is as high as 34 p.s.u. (GeoB 10013-1 and 10018-1). This pattern supports previous findings that the low-salinity tongue off western Sumatra (and thus, $\delta^{18} \mathrm{O}_{\mathrm{sw}}$ ), particularly in the fore-arc basins of Mentawai, Nias and Simeulue, "is linked to the freshwater input in the near-surface layer from rainfall and river runoff",43 rather than ocean advection. Sprintall et al. $^{44}$ and Janowiak and $\mathrm{Xie}^{45}$ also stated that the freshwater pool located on the equator off the west Sumatra coast is related to a 
regional maximum in precipitation, as well as contribution from river runoff. We expect that these fore-arc basins were even more detached from large-scale surface circulation in the Indian Ocean during the last glacial period, when sea level was mostly below their sill depth.

In addition, a stalagmite record from Borneo ${ }^{26}$ shows increased $\delta^{18} \mathrm{O}$ values (of rainfall) during Heinrich stadials, in line with increased $\delta^{18} \mathrm{O}_{\mathrm{sw}}$ values in marine records from the Sulu Sea ${ }^{46}$, the Lombok basin ${ }^{47}$ and the Timor Sea ${ }^{48}$ that lack any surface ocean connection to our study area. It is hard to explain such a consistent pattern in terrestrial and marine archives without involving changes in regional convective activity.

\section{Material and methods}

Piston cores SO189-119KL ( $3^{\circ} 31^{\prime} \mathrm{N}, 96^{\circ} 19^{\prime} \mathrm{E}$; 780-cm core length, 808-m water

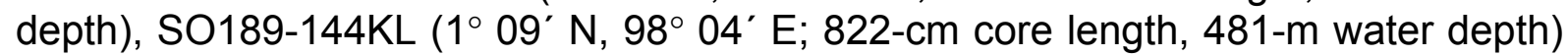
and SO189-39KL $\left(0^{\circ} 47^{\prime} \mathrm{S}, 99^{\circ} 54^{\prime} \mathrm{E}\right.$; $1,350-\mathrm{cm}$ core length, 517-m water depth) were collected from the upper continental margin in the Simeulue basin off northwestern Sumatra $(119 \mathrm{KL})$, from the Nias basin off northwestern Sumatra $(144 \mathrm{KL})$ and in the northern Mentawai basin off western Sumatra (39KL) during the RV Sonne cruise SO-18949. The cores were sampled at 5-cm (119KL) and 2-cm $(144 \mathrm{KL}, 39 \mathrm{KL})$ steps. Core-top studies from the Simeulue basin, the Nias basin and the northernMentawai basin suggest that these basins lack a calcite lysocline ${ }^{50,51}$. The presence of well-preserved pteropods throughout the cores, along with the SEM observation of planktonic foraminifera in the corresponding core-tops, further supports the inference that selective calcite dissolution is, and has been, negligible at these sites.

\section{Age models}

The age model of S0189-119KL is based on 14 accelerator mass spectrometry (AMS) ${ }^{14} \mathrm{C}$ dates and linear interpolation between them (Supplementary Table 1 and Extended Data Fig. 4). AMS ${ }^{14} \mathrm{C}$ dating was performed on mixed planktonic foraminifera at the National Ocean Sciences Accelerator Mass Spectrometry Facility (NOSAMS) in Woods Hole, USA. The age model of S0189-39KL is based on linear interpolation between 112 AMS ${ }^{14} \mathrm{C}$ dates performed on mixed planktonic foraminifera at NOSAMS (16 dates), on Globigerinoides ruber (41 dates), Globigerinoides sacculifer without the final sac-like chamber (45 dates), and on mixed G. ruber and G. sacculifer (10 dates) at the Keck Carbon Cycle Accelerator Mass Spectrometry Facility at the University of California in Irvine, USA (Supplementary Table 1 and Extended Data Fig. 4).The age model of SO189-144KL is based on linear interpolation between 36 AMS ${ }^{14} \mathrm{C}$ dates performed on mixed planktonic foraminifera at NOSAMS (26 dates), on $G$. ruber (4 dates), on $G$. sacculifer without the final sac-like chamber (4 dates), on mixed $G$. ruber and $G$. sacculifer (1 date), and on mixed planktonic foraminifera (1 date) at the Keck Carbon Cycle Accelerator Mass Spectrometry Facility at the University of California in Irvine, USA (Supplementary Table 1 and Extended Data Fig. 4). All ages were corrected for ${ }^{13} \mathrm{C}$, and ${ }^{14} \mathrm{C}$ ages were converted to calendar years using the CALIB 7.0 MARINE13 ${ }^{52}$ program without any local offset. This assumption is based on studies from the Andaman Islands ${ }^{53}$ and the Nicobar Islands ${ }^{54}$ showing insignificant deviations from the global reservoir effect ( $\Delta \mathrm{R}$ values of $11 \mathrm{yr}$ and $17 \mathrm{yr}$, respectively) in this region.

The correlation between the AMS ${ }^{14} \mathrm{C}$ dates in core $39 \mathrm{KL}$ shows statistically indistinguishable differences between the ages of monospecies and mixed species 
samples from the same core depths (Supplementary Fig. 1). We therefore included all the AMS ${ }^{14} \mathrm{C}$ dates in the age model and calculated an average age for each depth. In core $144 \mathrm{KL}$, mixed planktonic radiocarbon ages are on average about 200 $\mathrm{yr}$ older than the ages of the surface-dwelling species (G. ruber and G. sacculifer) during the Holocene, and about $500 \mathrm{yr}$ older during the last deglaciation (Supplementary Table 1). These age offsets are most probably due to the basin topography, which is characterized by relatively shallow sills that hamper a rigorous exchange between the subsurface waters of the Nias basin and the open ocean today. Accordingly, a lower sea-level stand during the last deglaciation increased the residence time of subsurface waters and the age offset between pure surface and mixed surface-subsurface radiocarbon dates to $500 \mathrm{yr}$. Therefore, the mixed planktonic ages were corrected by $200 \mathrm{yr}$ (Holocene) and $500 \mathrm{yr}$ (last deglaciation), respectively. Additional control of the calculated age model for core $144 \mathrm{KL}$ is provided by its stable oxygen isotope $\left(\delta^{18} \mathrm{O}\right)$ record, which perfectly matches the $\delta^{18} \mathrm{O}$ records of cores $39 \mathrm{KL}$ and $119 \mathrm{KL}$ (Fig. 1 and main text). According to the age models, the average sedimentation rate (SR) at $119 \mathrm{KL}$ is about $24 \mathrm{~cm} \mathrm{kyr}^{-1}$, with a higher average SR during MIS3 $\left(\sim 29 \mathrm{~cm} \mathrm{kyr}^{-1}\right)$ than during the last deglaciation $(\sim 20$ $\left.\mathrm{cm} \mathrm{kyr}^{-1}\right)$ and the Holocene $\left(\sim 19 \mathrm{~cm} \mathrm{kyr}^{-1}\right)$. The average SR at $144 \mathrm{KL}$ is about $43 \mathrm{~cm}$ $\mathrm{kyr}^{-1}$, with a higher average SR during the $\operatorname{LGM}\left(\sim 51 \mathrm{~cm} \mathrm{kyr} \mathrm{r}^{-1}\right)$ and the last deglaciation $\left(\sim 49 \mathrm{~cm} \mathrm{kyr}^{-1}\right)$ than during the Holocene $\left(\sim 31 \mathrm{~cm} \mathrm{kyr}^{-1}\right)$. The average SR at $39 \mathrm{KL}$ is about $34 \mathrm{~cm} \mathrm{kyr}^{-1}$, with no considerable differences between MIS3 ( 32 $\left.\mathrm{cm} \mathrm{kyr}^{-1}\right)$, the last deglaciation $\left(\sim 34 \mathrm{~cm} \mathrm{kyr}^{-1}\right)$ and the Holocene $\left(\sim 37 \mathrm{~cm} \mathrm{kyr}^{-1}\right)$.

\section{Stable oxygen isotope $\left(\delta^{18} \mathrm{O}\right)$ and $\mathrm{Mg} / \mathrm{Ca}$ of $\mathrm{G}$. ruber, seawater $\delta^{18} \mathrm{O}$}

In total, 147 (651) samples for $\delta^{18} \mathrm{O}$ and 135 (671) samples for $\mathrm{Mg} / \mathrm{Ca}$ were analyzed in core $119 \mathrm{KL}(39 \mathrm{KL})$. Additional 393 samples were analyzed for $\delta^{18} \mathrm{O}$ in core $144 \mathrm{KL}$. $\delta^{18} \mathrm{O}$ and $\mathrm{Mg} / \mathrm{Ca}$ analyses were performed on about 30 tests of $\mathrm{G}$. ruber sensu stricto $^{55}$ from the $250-355 \mu \mathrm{m}$ size-fraction. Previous sediment trap ${ }^{56}$ and sediment surface $^{50,51}$ studies suggest that $G$. ruber tests record mean annual mixed-layer conditions in the tropical eastern Indian Ocean, and particularly mean annual surface conditions in the study area ${ }^{51}$.

For $\delta^{18} \mathrm{O}$ analysis, the isotopic composition of the carbonate sample was measured at a Finnigan MAT 251 mass spectrometer on the $\mathrm{CO}_{2}$ gas evolved by treatment with phosphoric acid at a constant temperature of $75{ }^{\circ} \mathrm{C}$. For all stable isotope measurements a working standard was used, which has been calibrated against VPDB (Vienna PeeDee Belemnite) by using the NBS 19 standard. Long-term analytical standard deviation is about $\pm 0.07 \%$ (Isotope Laboratory at Faculty of Geosciences, University of Bremen).

For $\mathrm{Mg} / \mathrm{Ca}$ analysis, samples were cleaned applying a slightly modified method originally proposed by Barker et al. ${ }^{57}$ consisting of five water washes and two methanol washes followed by two oxidation steps with $1 \% \mathrm{NaOH}$-buffered $\mathrm{H}_{2} \mathrm{O}_{2}$, and

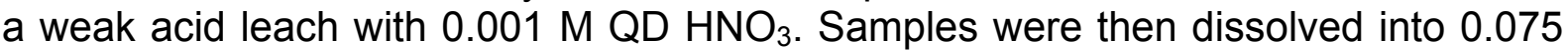
$\mathrm{M} \mathrm{QD} \mathrm{HNO}_{3}$ and centrifuged for 10 min. at 6,000 r.p.m., transferred into test tubes and diluted. $\mathrm{Mg} / \mathrm{Ca}$ ratios were measured using a Perkin Elmer Optima $3300 \mathrm{R}$ Inductively Coupled Plasma Optical Emission Spectrophotometer (ICP-OES) equipped with an auto sampler and an ultrasonic nebulizer U-5000 AT (Cetac Technologies Inc.) for samples from core 199KL, and an Agilent Technologies 700 Series ICP-OES with a CETAX ASX-520 auto sampler for samples from core 39KL (both housed at the Faculty of Geosciences, University of Bremen). Mg/Ca values are reported as mmol $\mathrm{mol}^{-1}$. Instrumental precision was determined using an external, in-house standard $\left(\mathrm{Mg} / \mathrm{Ca}=2.92 \mathrm{mmol} \mathrm{mol}^{-1}\right)$, which was run after every 
fifth sample. In core SO189-119KL, relative standard deviation was $0.008 \mathrm{mmol} \mathrm{mol}^{-1}$ $(0.26 \%)$ for the external standard and $0.07 \mathrm{mmol} \mathrm{mol}^{-1}(1.94 \%)$ for the ECRM 752-1 standard $^{58}$. Replicate measurements on 30 samples revealed an average standard deviation of $0.15 \mathrm{mmol} \mathrm{mol}^{-1}$. In core S0189-39KL, relative standard deviation was $0.005 \mathrm{mmol} \mathrm{mol}^{-1}(0.16 \%)$ for the external standard and $0.06 \mathrm{mmol} \mathrm{mol}^{-1}(1.66 \%)$ for the ECRM 752-1 standard. Replicate measurements on 55 samples revealed an average standard deviation of $0.12 \mathrm{mmol} \mathrm{mol}^{-1}$. Clay contamination and postdepositional Mn-rich carbonate/oxyhydroxides coatings could be excluded by measuring $\mathrm{Fe} / \mathrm{Ca}, \mathrm{Mn} / \mathrm{Ca}$, and $\mathrm{Al} / \mathrm{Ca}$ ratios $\left(<0.1 \mathrm{mmol} \mathrm{mol}{ }^{-1}\right.$ for $\mathrm{Mn} / \mathrm{Ca}$ and $\mathrm{Fe} / \mathrm{Ca}$, and not detectable for $\mathrm{Al} / \mathrm{Ca}$ ). $\mathrm{Mg} / \mathrm{Ca}$ ratios were converted to temperature following the equation proposed by Anand et al..$^{59}$ :

$\mathrm{Mg} / \mathrm{Ca}(\mathrm{mmol} / \mathrm{mol})=0.38 \exp ^{\left(0.09^{*}{ }^{\circ} \mathrm{C}\right)}$

In order to calculate seawater $\delta^{18} \mathrm{O}\left(\delta^{18} \mathrm{O} s w\right)$ as a measure of hydrologic changes, we used the $\delta^{18} \mathrm{O}$ :temperature equation of Bemis et al. ${ }^{60}$ :

$\mathrm{T}\left({ }^{\circ} \mathrm{C}\right)=14.9-4.8\left(\delta^{18} \mathrm{O}_{c c}-\delta^{18} \mathrm{O}_{s w}\right)$

where $\delta^{18} \mathrm{O}_{c c}$ is the measured $\delta^{18} \mathrm{O}$ of calcite and $\mathrm{T}$ the $\mathrm{Mg} / \mathrm{Ca}$-derived temperature. The values were then converted to Standard Mean Ocean Water (SMOW) by adding $0.27 \%$ and corrected for sea-level changes proposed by Waelbroeck et al. ${ }^{61}$.

\section{Error analysis on SST and $\delta^{18} \mathrm{O}_{\mathrm{sw}}$}

The errors of $\delta^{18} \mathrm{O}_{s w}$ and SST reconstructions are estimated by propagating the error introduced by the $\delta^{18} \mathrm{O}_{c c}$ and $\mathrm{Mg} / \mathrm{Ca}$ measurements (see previous section), $\mathrm{Mg} / \mathrm{Ca}$ :temperature calibration (1), $\delta^{18} \mathrm{O}$ :temperature equation (2), and the removal of global ice volume $( \pm 0.09 \%)^{61}$. For SST estimate, the following equation was used to propagate the errors by assuming no covariance among the errors ${ }^{62}$ :

$\sigma_{\mathrm{T}}^{2}=\left(\frac{\partial \mathrm{T}}{\partial \mathrm{a}} \sigma_{\mathrm{a}}\right)^{2}+\left(\frac{\partial \mathrm{T}}{\partial \mathrm{b}} \sigma_{\mathrm{b}}\right)^{2}+\left(\frac{\partial \mathrm{T}}{\partial \mathrm{Mg} / \mathrm{Ca}} \sigma_{\mathrm{Mg} / \mathrm{Ca}}\right)^{2}$

where

$\mathrm{a}=0.090 \pm 0.003^{\circ} \mathrm{C}^{-1}$

$\mathrm{b}=0.38 \pm 0.02 \mathrm{mmol} / \mathrm{mol}$

$\frac{\partial \mathrm{T}}{\partial \mathrm{a}}=\frac{-1}{\mathrm{a}^{2}} \ln \left(\frac{\mathrm{Mg} / \mathrm{Ca}}{\mathrm{b}}\right)$

$\frac{\partial T}{\partial b}=-\frac{1}{a b}$

and

$\frac{\partial \mathrm{T}}{\partial \mathrm{Mg} / \mathrm{Ca}}=\frac{1}{\mathrm{a}} \frac{1}{\mathrm{Mg} / \mathrm{Ca}}$

For $\delta^{18} \mathrm{O}_{\mathrm{sw}}$ estimate, the following equation was used to propagate the errors by assuming no covariance among the errors ${ }^{62}$. 
$\sigma_{\delta^{18} \mathrm{~S}_{\mathrm{sw}}}^{2}=\left(\frac{\partial \delta^{18} \mathrm{O}_{\mathrm{sW}}}{\partial \mathrm{T}} \sigma_{\mathrm{T}}\right)^{2}+\left(\frac{\partial \delta^{18} \mathrm{O}_{\mathrm{sW}}}{\partial \mathrm{a}} \sigma_{\mathrm{a}}\right)^{2}+\left(\frac{\partial \delta^{18} \mathrm{O}_{\mathrm{sW}}}{\partial \mathrm{b}} \sigma_{\mathrm{b}}\right)^{2}+\left(\frac{\partial \delta^{18} \mathrm{O}_{\mathrm{sW}}}{\partial \delta^{18} \mathrm{O}_{\mathrm{cc}}} \sigma_{\delta^{18} \mathrm{O}_{\mathrm{cc}}}\right)^{2}$

where

$\mathrm{a}=14.9 \pm 0.1^{\circ} \mathrm{C}$

$\mathrm{b}=-4.8 \pm 0.08^{\circ} \mathrm{C}$

$\frac{\partial \delta^{18} \mathrm{O}_{\mathrm{sw}}}{\partial \mathrm{T}}=-\frac{1}{\mathrm{~b}}$

$\frac{\partial \delta^{18} \mathrm{O}_{\mathrm{sw}}}{\partial \mathrm{a}}=\frac{1}{\mathrm{~b}}$

$\frac{\partial \delta^{18} \mathrm{O}_{\mathrm{sw}}}{\partial \mathrm{b}}=\frac{\mathrm{T}}{\mathrm{b}^{2}}-\frac{\mathrm{a}}{\mathrm{b}^{2}}$

and

$$
\frac{\partial \delta^{18} O_{s w}}{\partial \delta^{18} O_{c c}}=1
$$

The resulting errors are on average about $1^{\circ} \mathrm{C}$ for SST and $0.3 \%$ for $\delta^{18} \mathrm{O}_{\text {sw }}$ in cores 39KL and 119KL (Extended Data Fig. 5, Fig. 2, main text). We note that the absolute SST values in $119 \mathrm{KL}$ are about $1^{\circ} \mathrm{C}$ higher than in $39 \mathrm{KL}$ during the last deglaciation (Fig. 1, main text). This difference is probably related to the more open Simeulue Basin (site 119KL, see Extended Data Fig. 3). However, the calculated $\delta^{18} \mathrm{O}_{\mathrm{sw}}$ values for cores $119 \mathrm{KL}$ and $39 \mathrm{KL}$ are very similar suggesting little influence of SST on $\delta^{18} \mathrm{O}_{\mathrm{sw}}$, and that the latter parameter is mainly controlled by precipitation changes.

\section{Estimating the timing of deglacial warming}

In order to estimate the timing of deglacial warming from the $\mathrm{Mg} / \mathrm{Ca}$ record of core $39 \mathrm{KL}$ we applied a ramp-fitting method using the software RAMPFIT version 1.10 (http://www.manfredmudelsee.com/soft/rampfit) ${ }^{63}$. RAMPFIT has successfully been applied in previous studies for change-point detection in paleoclimatic time-series ${ }^{64-}$ 67. The simple ramp-function (three-phase) regression model assumes the existence of two distinct climate states, each of which is characterized by a constant parameter (here given by the SST of the cold glacial and the warm Holocene state), and a linear transition from one state to the other. Superimposed on this ramp function are shortterm climate variations and noise from measurement uncertainties making visual determination of the two break points (i.e. start and end of the transition) difficult. RAMPFIT uses weighted least-squares regression to determine the amplitude of the transition combined with a brute-force search for detecting start and end points. The time-dependent standard deviation provides the weights for the least-squares regression. A non-parametric stationary bootstrap re-sampling was used to estimate uncertainties in the timing of the transition, while age model uncertainties were not taken into account ${ }^{63}$.

Since the SST time-series of core $39 \mathrm{KL}$ shows a warming trend during the mid-to-late Holocene, data younger than 5 ka were excluded from the ramp regression analysis. Taking the entire glacial period (i.e. up to $45 \mathrm{ka} \mathrm{BP}$, the end of the SST record) into account, RAMPFIT estimates the onset of deglacial warming at $18.30 \pm 0.33 \mathrm{ka}(1 \sigma)$. 
This value is robust against the chosen interval length, e.g. excluding MIS3 (i.e. data older than $29 \mathrm{ka}$ BP) from the regression analysis leads to an estimated onset of deglacial warming at $18.29 \pm 0.44 \mathrm{ka}$ (Extended Data Fig. 6). The break point between the deglacial transition and the early Holocene warm state was found to be at $9.62 \pm 0.33 \mathrm{ka}$ and $9.75 \pm 0.39 \mathrm{ka}$ for the 5-45 ka and 5-29 ka intervals (Extended Data Fig. 6), respectively. Mean Mg/Ca SSTs before and after the deglacial transition are $26.29 \pm 0.03{ }^{\circ} \mathrm{C}$ and $29.18 \pm 0.06{ }^{\circ} \mathrm{C}$, respectively, when taking the $5-45 \mathrm{ka}$ interval and $26.27 \pm 0.06{ }^{\circ} \mathrm{C}$ and $29.16 \pm 0.07{ }^{\circ} \mathrm{C}$ when taking the shorter $5-29 \mathrm{ka}$ interval.

Ramp-function regression has not been applied to the $\mathrm{Mg} / \mathrm{Ca}$ record of core $119 \mathrm{KL}$ due to its too coarse temporal resolution. Visual inspection however clearly suggests deglacial warming to start at $\sim 18 \mathrm{ka} \mathrm{BP}$, i.e. synchronous to atmospheric $\mathrm{CO}_{2}$ and high-latitude temperature change as estimated from Antarctic ice cores ${ }^{22}$.

\section{Correlation between $\delta^{18} \mathrm{O}_{\mathrm{sw}}$ in $39 \mathrm{KL}$ and $\delta \mathrm{D}$ in Lake Tanganyika}

The correlation between the $\delta^{18} \mathrm{O}_{\text {sw }}$ record of SO189-39KL and the $\delta \mathrm{D}$ record of Lake Tanganyika ${ }^{14}$ (Fig. 2, main text) was tested by using the improved version of PearsonT software ${ }^{68}$ (PearsonT3, www.climate-risk-analysis.com). The software estimates correlation coefficient $(r)$ with accurate bootstrap confidence intervals by accounting for auto correlation (memory) of the data ${ }^{68}$. The two datasets were resampled at $0.3 \mathrm{kyr}$ steps based on their original age models in order to achieve the same timescale. The correlation coefficient at $95 \%$ confidence interval for the period 1.5 to $45 \mathrm{ka}$ is $r=0.43[0.11 ; 0.67]$. Since the confidence interval does not contain zero the correlation between the two records is significant.

\section{Numerical Experiments}

For the numerical experiments, the comprehensive global climate model CCSM3 (Community Climate System Model version 3) was used. NCAR's (National Center for Atmospheric Research) CCSM3 is a state-of-the-art fully-coupled model, composed of four separate components representing atmosphere, ocean, land and sea-ice $^{69}$. In our simulations, the resolution of the atmospheric component is given by T31 (3.75 transform grid) with 26 layers in the vertical, while the ocean has a nominal resolution of $3^{\circ}$ with equatorial grid refinement in meridional direction (down to $0.9^{\circ}$ ) and 25 levels in the vertical ${ }^{70}$. The land model is defined on the same horizontal grid as the atmosphere and includes components for biogeophysics, biogeochemistry, the hydrologic cycle as well as a dynamic global vegetation model $^{71,72}$. In order to improve the simulation of the land surface hydrology and vegetation cover, new parameterizations for canopy interception and soil evaporation have been implemented into the land component ${ }^{73}$. Our experimental framework comprises four glacial simulations:

(1) A baseline simulation for the Last Glacial Maximum (LGM) following the guidelines of the Paleoclimate Modeling Intercomparison Project, Phase $2^{74}$. The boundary conditions for this simulation comprise the orbital parameters of $21 \mathrm{ka}$ $\mathrm{BP}^{75}$ and the greenhouse gas concentrations of $\mathrm{CO}_{2}, \mathrm{CH}_{4}$ and $\mathrm{N}_{2} \mathrm{O}$ (185 ppm, $350 \mathrm{ppb}$, and $200 \mathrm{ppb}$, respectively). A sea-level lowering by $120 \mathrm{~m}$ has been taken into account by modifying the land-sea distribution which, in particular, leads to closure of the Bering Strait. In addition, LGM continental ice-sheets have been implemented based on the ICE-5G dataset ${ }^{76}$. The experimental setup differs from the LGM run by Merkel et al. ${ }^{77}$ only in the land surface component (see above). Our LGM simulation was integrated for 1500 years, starting from the quasi-equilibrated LGM run of Merkel et al. ${ }^{77}$. 
(2) A H1 (Heinrich Stadial 1) analog experiment in which the LGM climate state is perturbed by a constant freshwater input of $0.2 \mathrm{~Sv}\left(1 \mathrm{~Sv}=10^{6} \mathrm{~m}^{3} / \mathrm{s}\right)$ to the northern North Atlantic leading to a substantial weakening of the Atlantic Meridional Overturning Circulation (AMOC). The hosing experiment was integrated for 500 years. Note that the applied freshwater forcing is in the range of published estimates for meltwater input during Heinrich events ${ }^{23}$.

(3) A Marine Isotope Stage (MIS) 3 baseline simulation in which the LGM boundary conditions (see above) were modified by applying $38 \mathrm{ka}$ BP orbital forcing and corresponding greenhouse gas concentrations of $\mathrm{CO}_{2}, \mathrm{CH}_{4}$ and $\mathrm{N}_{2} \mathrm{O}(215 \mathrm{ppm}$, $501 \mathrm{ppb}$, and $234 \mathrm{ppb}$, respectively) ${ }^{78-80}$. In addition, the $38 \mathrm{ka}$ BP ICE-5G continental ice-sheet distribution has been implemented ${ }^{76}$. The MIS3 baseline simulation was initialized with the final state of our LGM simulation and integrated for another 2100 years.

(4) A H4 (Heinrich Stadial 4) simulation in which the MIS3 (38 ka BP) baseline climate is perturbed by a constant $0.2 \mathrm{~Sv}$ freshwater influx analog to the $\mathrm{H} 1$ experiment. The $\mathrm{H} 4$ hosing experiment starts at year 1600 of our MIS3 baseline run and was integrated for 500 years.

In all simulations, ozone and aerosol distributions were kept at pre-industrial levels ${ }^{81}$. For each experiment, the mean of the last 100 simulation years was used for analysis.

Extended Data Fig. 7 shows the Atlantic meridional overturning stream-functions for the four different glacial climate states along with a pre-industrial reference run. The LGM North Atlantic overturning is slightly (1-2 Sv) stronger than the pre-industrial circulation, but the southward flow of North Atlantic Deep Water takes place at shallower depth. The AMOC is similarly strong in the MIS3 baseline run. Upon freshwater input to the North Atlantic, the AMOC weakens rapidly under both LGM and MIS3 boundary conditions.

Extended Data Fig. 8 shows the annual mean climatic response to AMOC slowdown under LGM boundary conditions (H1 experiment) for large-scale surface temperature and mid-tropospheric vertical velocity in the Indian Ocean region. Comparing the results of the $\mathrm{H} 1$ experiment with the $\mathrm{H} 4$ run (Fig. 3, main text) suggests that the same mechanisms are at work, involving a southward shift of the ascending branch of the annual mean Hadley circulation. For the same region, the mid-tropospheric vertical velocity is shown in Supplementary Information Fig. S2 for both the LGM and MIS3 baseline simulations as a reference. Rising air over the equatorial region with subsidence to the north and south of it reveals the regional annual mean Hadley circulation in both climate states.

\section{Indian summer monsoon weakening and atmospheric Atlantic Ocean-India teleconnection}

As part of the Hadley cell reorganization during Heinrich Stadials, the Indian summer monsoon weakens (Extended Data Fig. 9). The model results suggest a rapid response of the Indian monsoon to North Atlantic cooling through both a stationary Rossby wave train teleconnection that originates in the northern North Atlantic and a tropical atmospheric pathway.

The 200-hPa wind field anomaly (H4 hosing experiment minus MIS3 baseline run) in summer exhibits an arch-shaped wave train that propagates south-eastwards from the northern North Atlantic region of perturbation to west-central Asia via east-central Europe, and further, zonally across Asia towards the Pacific Ocean along the westerly jet (Extended Data Fig. 10). Except north and northwest of India this wave 
train has an equivalent barotropic structure (not shown). Analyzing modern observational data, a similar wave train has been identified as part of a circumglobal teleconnection pattern in the summertime mid-latitude circulation of the northern hemisphere, which significantly correlates with Indian monsoonal rainfall at the interannual timescale ${ }^{82}$. It has been suggested that the upper-level circulation anomaly affects Indian rainfall by changing the intensity of the monsoonal easterly vertical shear and its associated moist dynamic instability ${ }^{82,83}$. A westerly flow anomaly that stretches from North Africa to western India via the Arabian Sea adds to the upper-level circulation anomaly in the Indian monsoon region (Extended Data Fig. 10). A similar circulation anomaly over Africa and the Arabian Sea was recently found in freshwater hosing experiments by Marzin et al. ${ }^{3}$ and, by means of atmosphere-only sensitivity experiments, could be attributed to anomalous sea surface temperature forcing in the tropical Atlantic ("tropical pathway").

Unrelated to the Indian summer monsoon an equivalent barotropic wave train propagating south-eastward from the northern North Atlantic source region is also found in the Heinrich Stadial winter circulation anomaly (Extended Data Fig. 10). Compared to the summer season, the wave path is shifted towards the equator following the seasonal jet stream displacement, crossing the Mediterranean Sea and the Arabian Peninsula until it reaches India where an anticyclonic circulation anomaly establishes in the upper troposphere. We surmise that this anomalous anticyclone promotes the upper-level southeasterly cross-equatorial flow over the Indian Ocean (Extended Data Fig. 10), which contributes to anomalous energy transport from the southern hemisphere to the anomalously cold northern hemisphere (c.f. ${ }^{24,84}$ ). The increased energy demand of the northern hemisphere during Heinrich Stadials is particularly large in the boreal winter season when the northern hemisphere cooling is strongest (Supplementary Information Fig. S3) mainly due to sea-ice effects (increased surface albedo and reduced ocean-atmosphere heat flux in the northern North Atlantic). We note that atmospheric circulation and precipitation response patterns are qualitatively the same in the $\mathrm{H} 1$ and $\mathrm{H} 4$ experiments (not shown).

\section{Methods references}

31 Antonov, J. I., Locarnini, R. A., Boyer, T. P., Mishonov, A. V. \& Garcia, H. E. World Ocean Atlas 2005, Volume 2: Salinity. 182 (U.S. Government Printing Office, 2006).

32 Aldrian, E. \& Susanto, R. D. Identification of three dominant rainfall regions within Indonesia and their relationship to sea surface temperature. International Journal of Climatology 23, 1435-1452 (2003).

33 Wang, B. \& Ding, Q. Global monsoon: Dominant mode of annual variation in the tropics. Dynamics of Atmospheres and Oceans 44, 165-183 (2008).

34 Yoo, S.-H., Yang, S. \& Ho, C.-H. Variability of the Indian Ocean sea surface temperature and its impacts on Asian-Australian monsoon climate. Journal of Geophysical Research 111, D03108, doi:03110.01029/02005JD006001 (2006).

35 Schott, F. A. \& McCreary, J. P. The monsoon circulation of the Indian Ocean. Progress In Oceanography 51, 1-123 (2001).

36 Sengupta, D., Raj, G. N. B. \& Shenoi, S. S. C. Surface freshwater from Bay of Bengal runoff and Indonesian Throughflow in the tropical Indian Ocean. Geophysical Research Letters 33, L22609, doi:22610.21029/22006GL027573 (2006).

37 Schott, F. A., Xie, S.-P. \& McCreary, J. P., Jr. Indian Ocean circulation and climate variability. Review of Geophysics 47, RG1002, doi:1010.1029/2007RG000245 (2009).

38 Vinayachandran, P. N., Murty, V. S. N. \& Ramesh Babu, V. Observations of barrier layer formation in the Bay of Bengal during summer monsoon. Journal of Geophysical Research 107, 8018, doi:10.1029/2001jc000831 (2002). 
39 Qu, T., Du, Y., Strachan, J., Meyers, G. \& Slingo, J. M. Sea surface temperature and its variability in the Indonesian region. Oceanography 18, 50-62 (2005).

40 Du, Y., Qu, T., Meyers, G., Masumoto, Y. \& Sasaki, H. Seasonal heat budget in the mixed layer of the southeastern tropical Indian Ocean in a high-resolution ocean general circulation model. Journal of Geophysical Research 110, C04012, doi:04010.01029/02004JC002845 (2005).

$41 \mathrm{Qu}, \mathrm{T}$. \& Meyers, G. Seasonal variation of barrier layer in the southeastern tropical Indian Ocean. Journal of Geophysical Research 110, C11003, doi:11010.11029/12004JC002816 (2005).

42 Sprintall, J. \& Tomczak, M. Evidence of the Barrier Layer in the Surface Layer of the Tropics. Journal of Geophysical Research 97, 7305-7316, doi:10.1029/92jc00407 (1992).

43 Qiu, Y., Cai, W., Li, L. \& Guo, X. Argo profiles variability of barrier layer in the tropical Indian Ocean and its relationship with the Indian Ocean Dipole. Geophysical Research Letters 39, L08605, doi:08610.01029/02012gl051441, doi:10.1029/2012gl051441 (2012).

44 Sprintall, J., Potemra, J. T., Hautala, S. L., Bray, N. A. \& Pandoe, W. W. Temperature and salinity variability in the exit passages of the Indonesian Throughflow. Deep Sea Research Part II: Topical Studies in Oceanography 50, 2183-2204 (2003).

45 Janowiak, J. E. \& Xie, P. CAMS-OPI: a global satelliterain gauge merged product for real-time precipitation monitoring applications. Journal of Climate 12, 3335-3342 (1999).

46 Rosenthal, Y., Oppo, D. W. \& Linsley, B. K. The amplitude and phasing of climate change during the last deglaciation in the Sulu Sea, western equatorial Pacific. Geophysical Research Letters 30, 1428, doi:1410.1029/2002GL016612 (2003).

47 Levi, C. et al. Low-latitude hydrological cycle and rapid climate changes during the last deglaciation. Geochemistry, Geophysics, Geosystems 8, Q05N12, doi:10.1029/2006GC001514 (2007).

48 Zuraida, R. et al. Evidence for Indonesian Throughflow slowdown during Heinrich events 3-5. Paleoceanography 24, PA2205, doi:2210.1029/2008PA001653 (2009).

49 Wiedicke-Hombach, M. et al. SUMATRA - The hydrocarbon system of the Sumatra forearc. Vol. Archive No. 0126492 (Federal Institute for Geosciences and Natural Resources (BGR) Hannover, 2007).

50 Mohtadi, M. et al. Modern environmental conditions recorded in surface sediment samples off W and SW Indonesia: planktonic foraminifera and biogenic compounds analyses. Marine Micropaleontology 65, 96-112 (2007).

51 Mohtadi, M. et al. Reconstructing the thermal structure of the upper ocean: Insights from planktic foraminifera shell chemistry and alkenones in modern sediments of the tropical eastern Indian Ocean. Paleoceanography 26, PA3219, doi:3210.1029/2011pa002132, doi:10.1029/2011pa002132 (2011).

52 Reimer, P. J. et al. IntCal13 and Marine13 Radiocarbon Age Calibration Curves 050,000 Years cal BP. Radiocarbon 55, 1869-1887, doi:10.2458/azu_js_rc.55.16947 (2013).

53 Dutta, K., Bhushan, K. \& Somayajulu, B. L. K. $\Delta$ R correction values for the northern Indian Ocean. Radiocarbon 43, 483-488 (2001).

54 Southon, J., Kashgarian, M., Fontugne, M., Metivier, B. \& Yim, W. W.-S. Marine reservoir corrections for the Indian Ocean and southeast Asia. Radiocarbon 44, 167 180 (2002).

55 Wang, L. Isotopic signals in two morphotypes of Globigerinoides ruber (white) from the South China Sea: implications for monsoon climate change during the last glacial cycle. Palaeogeography, Palaeoclimatology, Palaeoecology 161, 381-394 (2000).

56 Mohtadi, M. et al. Low-latitude control on seasonal and interannual changes in planktonic foraminiferal flux and shell geochemistry off south Java: A sediment trap study. Paleoceanography 24, PA1201, doi:1210.1029/2008PA001636 (2009). 
57 Barker, S., Greaves, M. \& Elderfield, H. A study of cleaning procedures used for foraminiferal Mg/Ca paleothermometry. Geochemistry, Geophysics, Geosystems 4, 8407, doi:8410.1029/2003GC000559 (2003).

58 Greaves, M. et al. Interlaboratory comparison study of calibration standards for foraminiferal $\mathrm{Mg} / \mathrm{Ca}$ thermometry. Geochemistry, Geophysics, Geosystems 9, Q08010, doi:08010.01029/02008GC001974 (2008).

59 Anand, P., Elderfield, H. \& Conte, M. H. Calibration of $\mathrm{Mg} / \mathrm{Ca}$ thermometry in planktonic foraminifera from a sediment trap time series. Paleoceanography 18 , 1050, doi:1010.1029/2002PA000846 (2003).

60 Bemis, B. E., Spero, H. J., Bijma, J. \& Lea, D. W. Reevaluation of the oxygen isotopic composition of planktonic foraminifera: Experimental results and revised paleotemperature equations. Paleoceanography 13, 150-160 (1998).

61 Waelbroeck, C. et al. Sea-level and deep water temperature changes derived from benthic foraminifera isotopic records. Quaternary Science Reviews 21, 295-305 (2002).

62 Bevington, P. R. \& Robinson, D. K. Data reduction and error analysis for the physical sciences. 3 edn, 320 (McGraw-Hill, 2003).

63 Mudelsee, M. Ramp function regression: A tool for quantifying climate transitions. Computers and Geosciences 26, 293-307 (2000).

64 Fleitmann, D. et al. Holocene forcing of the Indian monsoon recorded in a stalagmite from Southern Oman. Science 300, 1737-1739 (2003).

65 Fleitmann, D. et al. Timing and climatic impact of Greenland interstadials recorded in stalagmites from northern Turkey. Geophysical Research Letters 36, L19707, doi:10.1029/2009gl040050 (2009).

66 Steffensen, J. P. et al. High-Resolution Greenland Ice Core Data Show Abrupt Climate Change Happens in Few Years. Science 321, 680-684, doi:10.1126/science.1157707 (2008).

67 Mudelsee, M. \& Raymo, M. E. Slow dynamics of the Northern Hemisphere Glaciation. Paleoceanography 20, PA4022, doi:4010.1029/2005PA001153 (2005).

68 Mudelsee, M. Estimating Pearson's Correlation Coefficient with Bootstrap Confidence Interval from serially dependent time series. Mathematical Geology 35, 651-665 (2003).

69 Collins, W. D. et al. The Community Climate System Model version 3 (CCSM3). Journal of Climate 19, 2122-2143 (2006).

70 Yeager, S. G., Shields, C. A., Large, W. G. \& Hack, J. J. The low-resolution CCSM3. Journal of Climate 19, 2545-2566 (2006).

71 Levis, S., Bonan, G. B., Vertenstein, M. \& Oleson, K. W. The Community Land Model's Dynamic Global Vegetation Model (CLM-DGVM): Technical Description and User's Guide. (National Center for Atmospheric Research, 2004).

72 Oleson, K. et al. Technical Description of the Community Land Model (CLM). (National Center for Atmospheric Research, 2004).

73 Oleson, K. W. et al. Improvements to the Community Land Model and their impact on the hydrological cycle. Journal of Geophysical Research 113, G01021, doi:01010.01029/02007JG000563 (2008).

74 Braconnot, P. et al. Results of PMIP2 coupled simulations of the Mid-Holocene and Last Glacial Maximum - Part 1: experiments and large-scale features. Climate of the Past 3, 261-277, doi:10.5194/cp-3-261-2007 (2007).

75 Berger, A. L. Long-term variations of daily insolation and Quaternary climate changes. Journal of atmospheric sciences 35, 2362-2367 (1978).

76 Peltier, W. R. Global glacial isostasy and the surface of the ice-age Earth: the ICE-5G (VM2) model and GRACE. Ann. Rev. Earth Planet. Science 32, 111-149 (2004).

77 Merkel, U., Prange, M. \& Schulz, M. ENSO variability and teleconnections during glacial climates. Quaternary Science Reviews 29, 86-100 (2010).

78 Flückiger, J. et al. $\mathrm{N}_{2} \mathrm{O}$ and $\mathrm{CH}_{4}$ variations during the last glacial epoch: insight into global processes. Global Biogecheomical Cycles 18, GB1020. doi:1010.1029/2003GB002122 (2004). 
79 Spahni, R. et al. Atmospheric methane and nitrous oxide of the Late Pleistocene from Antarctic ice cores. Science 310, 1317-1321 (2005).

80 Ahn, J. \& Brook, E. J. Atmospheric $\mathrm{CO} 2$ and climate from 65 to 30 ka B.P. Geophysical Research Letters 34, L10703, doi:10710.11029/12007GL029551 (2007).

81 Otto-Bliesner, B. L. et al. Climate sensitivity of moderate- and low-resolution versions of CCSM3 to preindustrial forcings. Journal of Climate 19, 2567-2583 (2006).

82 Ding, Q. \& Wang, B. Circumglobal teleconnection in the Northern Hemisphere summer. Journal of Climate 18, 3483-3505, doi:10.1175/JCLI3473.1 (2005).

83 Ding, Q. \& Wang, B. Intraseasonal teleconnection between the summer Eurasian wave train and the Indian Monsoon. Journal of Climate 20, 3751-3767, doi:10.1175/JCLI4221.1 (2007).

84 Broccoli, A. J., Dahl, K. A. \& Stouffer, R. J. Response of the ITCZ to Northern Hemisphere cooling. Geophysical Research Letters 33, L01702, doi:01710.01029/02005gl024546, doi:10.1029/2005gl024546 (2006).

\section{Extended Data legends}

Extended Data Figure 1. Instrumental records of temperature and precipitation in the study area. Records are at or close to the sites 119KL (black) and 39KL (red). a, Average monthly SST for the Simeulue basin $\left(4^{\circ} \mathrm{N}, 96^{\circ} \mathrm{E}\right.$; black) and the northern Mentawai basin $\left(2^{\circ} \mathrm{S}, 100^{\circ} \mathrm{E}\right.$; red) based on extended reconstruction sea surface temperature (ERSST) data from 1854 to 2008 (http://nomads.ncdc.noaa.gov/las/getUl.do). Dashed lines indicate average SST for the entire period. b, Twenty-four-hour air temperatures measured in Sabang in northwestern Sumatra (from1976 to 1989; black) and in Padang in western Sumatra (from 1850 to 1989; red; http://climexp.knmi.nl). Dashed lines indicate the average air temperature over the entire period. c, Average monthly precipitation ( $\mathrm{mm}$ per month) over Banda Aceh in northwestern Sumatra (black) and Padang (red), between 1879 and 1989 (http://climexp.knmi.nl). Open circles represent mean monthly precipitation of different seasons (winter, spring, summer and autumn), with the numbers indicating the percentage contribution of each season to the total annual precipitation. Dashed lines indicate average monthly precipitation for the entire period. Note the small seasonality of SST, air temperature and precipitation in the study area.

Extended Data Figure 2. Seasonality of surface currents, SST and salinity in the eastern Indian Ocean. Seasonal changes in SST (colour shading), salinity (dashed lines; p.s.u.) and surface currents (arrows) in the study area during boreal summer (top) and winter (bottom). The meridional Ekman transport (MET) is also indicated with arrows. Seasonal SST is averaged for the period between 2002 and 2010 (http://oceancolor.gsfc.nasa.gov/cgi//3). Salinities are averaged for the period between 1960 and $2004^{31}$. Surface currents and MET are redrawn following ref. 35 . Note the seasonal reversal of the surface currents and the MET, and the small seasonality of SST and salinity off western and northwestern Sumatra. The positions of the cores from the tropical eastern Indian Ocean are indicated by stars (this study). NECC, north equatorial counter current; NMC, northeast monsoon current; SECC, south equatorial counter current; SJC, south Java current; SMC, southwest monsoon current.

Extended Data Figure 3. Sill depths in the study area. Sill depths of the Simeulue Basin (1-3), the Nias Basin (4-6) and the Northern Mentawai Basin (7-9), with the 
position of the cores indicated (yellow dots). The maximum depth of each sill is as indicated.

Extended Data Figure 4. Age-depth relationship of the investigated cores. Core depth $(\mathrm{cm})$ versus calendar age (years) with $2 \sigma$ errors (bars and yellow envelope) in cores 119KL (a), 144KL (b) and 39KL (c).

Extended Data Figure 5. Estimated errors $(1 \sigma)$ for SST and $\delta^{18} \mathrm{O}_{\mathrm{sw}}$ in core 119KL. Grey envelopes indicate errors in reconstructions of SST (a) and $\delta^{18} \mathrm{O}_{\text {sw }}(\mathbf{b})$. For comparison, the $39 \mathrm{KL}$ records (red) are shown. Grey bars indicate $2 \sigma$ errors of the calibrated radiocarbon ages (black and red triangles).

Extended Data Figure 6. Mg/Ca SST record of core 39KL for the period 5-29 kyr ago, along with the fitted ramp function (red).

Extended Data Figure 7. AMOC for different climate states, as simulated by CCSM3. Meridional overturning stream function averaged over the last $100 \mathrm{yr}$ of each experiment for the MIS3 baseline run (a), the H4 hosing experiment (b), the LGM simulation (c), the $\mathrm{H} 1$ hosing experiment (d) and the pre-industrial control run (e).

Extended Data Figure 8. Climatic response to a substantial slowdown of the AMOC under LGM (21 kyr ago) boundary conditions in a CCSM3 simulation. Shown are long-term (100-yr) annual means of climatic anomalies (Heinrich stadial 1 hosing experiments minus LGM baseline run) for surface temperature (a) and vertical velocity (b) at $500 \mathrm{hPa}$.

Extended Data Figure 9. Summer (June, July and August) precipitation response to a substantial slowdown of the AMOC under MIS3 (38 kyr ago) boundary conditions, as simulated by CCSM3. Shown are 100-yr averages (Heinrich stadial 4 hosing experiment minus MIS3 baseline run).

Extended Data Figure 10. Upper-tropospheric $(200 \mathrm{hPa})$ wind response to a substantial slowdown of the AMOC (Heinrich stadial 4 hosing experiment minus MIS3 baseline run; 100-yr averages). a, Summer (June, July and August) response; b, winter (December, January and February) response. Wave trains are highlighted by plus symbols (positive geopotential height anomaly/anticyclonic circulation anomaly) and minus symbols (negative geopotential height anomaly/cyclonic circulation anomaly). 